\title{
Synthesis and Structure of novel Triphenylarsine-substituted
}

\section{Tungsten(0) Fischer carbene complexes}

Armand Jansen van Rensburg, ${ }^{a}$ Marilé Landman, ${ }^{a}{ }^{*}$ Petrus H. van Rooyen, ${ }^{a}$ Marrigje M. Conradie $^{b}$ and Jeanet Conradie ${ }^{b}$

a Department of Chemistry, University of Pretoria, Private Bag X20, Hatfield, 0028, South Africa. Tel: 27-124202527, Fax: 27-12-4204687

b Department of Chemistry, University of the Free State, PO Box 339, Bloemfontein, 9300, South Africa. Tel: 27-51-4012194, Fax: 27-51-4017295

Contact author details:

Name: Jeanet Conradie, Tel: ++27-51-4012194, Fax: ++27-51-4017295, email: conradj@ufs.ac.za

Name: Marilé Landman Tel: ++27-12-4202527, Fax: ++27-12-4204687, email: marile.landman@up.ac.za

\section{SYNOPSIS TOC}

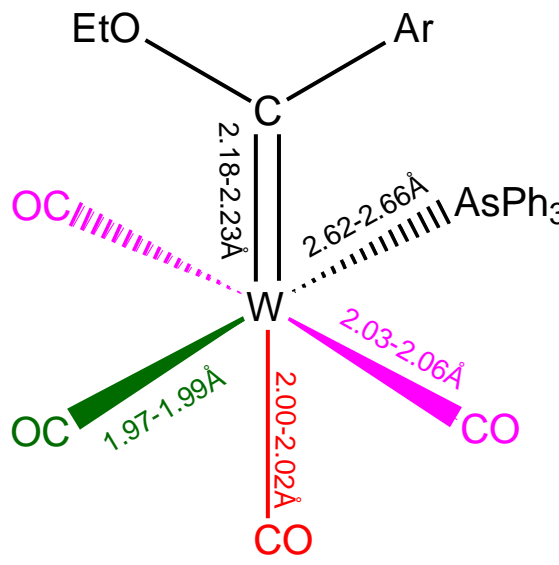

$$
\begin{gathered}
\mathrm{Ar}=\mathrm{C}_{4} \mathrm{H}_{3} \mathrm{O}, \mathrm{C}_{4} \mathrm{H}_{3} \mathrm{~S}, \\
\mathrm{C}_{4} \mathrm{H}_{3} \mathrm{NMe}, \mathrm{C}_{4} \mathrm{H}_{2} \mathrm{~S}-\mathrm{C}_{4} \mathrm{H}_{3} \mathrm{~S}
\end{gathered}
$$

\section{Highlights}

- Structure of cis triphenylarsine-substituted tungsten(0) Fischer-type carbenes.

- W-C bond trans $\mathrm{AsPh}_{3}<\mathrm{W}-\mathrm{C}$ bond trans carbene $<\mathrm{W}-\mathrm{C}$ bond trans $\mathrm{CO}$.

- Trans-influence for tetracarbonyl W(0)-carbenes: $\mathrm{CO}>\mathrm{PPh}_{3}>\mathrm{AsPh}_{3}$. 


\begin{abstract}
X-ray crystal structure determination, as well as IR and NMR spectroscopy of four novel triphenylarsine-substituted tetracarbonyl tungsten(0) Fischer carbene complexes of general formula $\left[(\mathrm{CO})_{4}\left(\mathrm{AsPh}_{3}\right) \mathrm{WC}(\mathrm{OEt})(\mathrm{Ar})\right]$, with $\mathrm{Ar}=$ 2-thienyl (1), 2-furyl (2), 2-(Nmethyl)pyrrolyl (3), 2,2'-bithienyl (4), revealed a cis-configuration for the substituted $\mathrm{AsPh}_{3}$ group relative to the carbene ligand for all four novel complexes. All X-ray structures showed that the $\mathrm{W}-\mathrm{C}$ bond trans $\mathrm{AsPh} 3<\mathrm{W}-\mathrm{C}$ bond trans carbene $<\mathrm{W}-\mathrm{C}$ bond trans CO. DFT calculations on all possible conformations of each complex due to the different possible positions of the ligands and carbene substituents to each other, correlated with the experimental results.
\end{abstract}

\title{
Keywords
}

Fischer carbene; Tungsten; Triphenylarsine; conformations; DFT

\section{Introduction}

In 1964, Fischer and Maasböl synthesized the first carbene complex, [(CO) 5 WC(OMe $)(\mathrm{Ph})]$, (Figure 1), where they described the bonding pattern between the carbene ligand and the metal as a formal carbon-metal double bond [1]. Three years later, Fischer and Klabunde showed that the reaction of $\left[(\mathrm{CO})_{5} \mathrm{CrC}(\mathrm{OMe})(\mathrm{Me})\right]$ with ammonia or thiophenol yielded the substitution complexes $\left[(\mathrm{CO})_{5} \mathrm{CrC}\left(\mathrm{NH}_{2}\right)(\mathrm{Me})\right]$ and $\left[(\mathrm{CO})_{5} \mathrm{CrC}(\mathrm{SPh})(\mathrm{Me})\right]$, (Figure 1), with the liberation of methanol [2]. In 1969 Fischer reported the synthesis of the first ligandsubstituted Fischer alkoxycarbene complexes. Complexes of the type cis$\left[\left(\mathrm{EPh}_{3}\right)(\mathrm{CO})_{4} \mathrm{MC}(\mathrm{OMe})(\mathrm{Me})\right]$ with $\mathrm{E}=\mathrm{P}, \mathrm{As}, \mathrm{Sb}$ and $\mathrm{M}=\mathrm{Cr}$, Mo, W (Figure 1) were synthesized from $\left[\left(\mathrm{EPh}_{3}\right)(\mathrm{CO})_{5} \mathrm{M}\right]$, showing that the ligand sphere around the metal can be altered before carbene synthesis [3]. However, seven years later it was also shown that ligand substitution could also be achieved after carbene formation by substituting a carbonyl ligand of the pentacarbonyl Fischer carbene complex. Fischer and Richter were able to synthesize complexes of the type cis/trans-[(ER 3$\left.)(\mathrm{CO})_{4} \mathrm{CrC}(\mathrm{OMe})(\mathrm{Me})\right]$ with $\mathrm{R}=\mathrm{Me}, \mathrm{Et}, \mathrm{Cy}, \mathrm{Ph}$ and $\mathrm{E}$ $=\mathrm{P}, \mathrm{As}, \mathrm{Sb}[4]$, as shown in Figure 1 . 

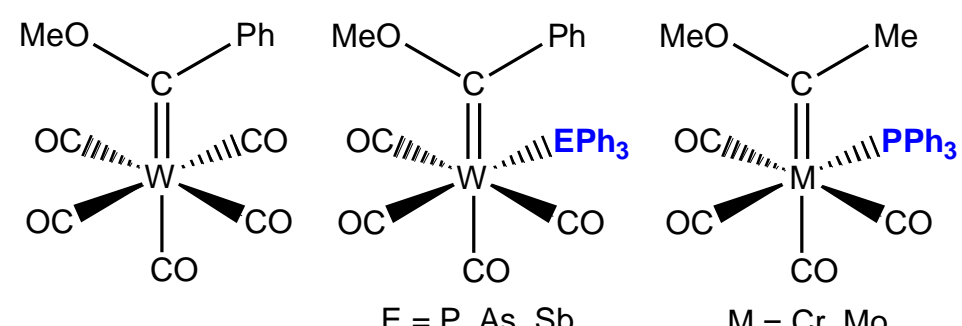

$\mathrm{E}=\mathrm{P}, \mathrm{As}, \mathrm{Sb}$

$\mathrm{M}=\mathrm{Cr}, \mathrm{Mo}$
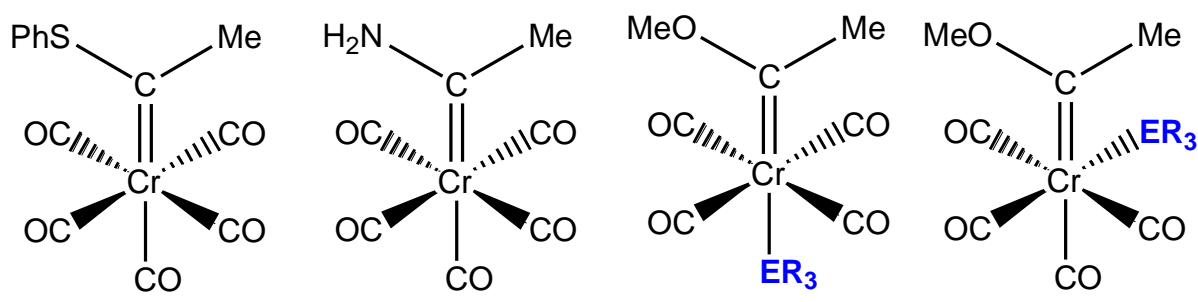

$\mathrm{E}=\mathrm{P}, \mathrm{As}, \mathrm{Sb}$

$\mathrm{R}=\mathrm{Me}, \mathrm{Et}, \mathrm{Cy}, \mathrm{Ph}$

Figure 1. Selection of Fischer carbene complexes synthesized by Fischer and associates [1-4]

Arsines are similar to phosphines, neutral $\sigma$-donor and $\pi$-acceptor ligands. A vast number of tungsten complexes have been synthesized containing the ligand $\mathrm{AsR}_{3}$, where $\mathrm{R}$ is an alkyl or aryl group [5-10]. Fischer et al. were successful in synthesizing triphenylarsine-substituted chromium(0) allenylidene complexes, which can be employed in catalytic and stoichiometric organic transformations [5]. Nitrile-substitution with arsines yielded seven-coordinate tungsten(II) complexes, which may find use as precatalysts for olefin metathesis [6]. Further, tungsten(II) complexes with a bidentate arsine-ligand was prepared by Mihichuk in a structural study [8], which may be used similarly as the monodentate analogues of Baker [6]. The steric and electronic properties of ligand $\mathrm{EPh}_{3}$ in $\left[(\mathrm{CO})_{4} \mathrm{M}\left(\mathrm{EPh}_{3}\right)_{2}\right](\mathrm{E}=\mathrm{P}, \mathrm{As}, \mathrm{Sb} ; \mathrm{M}=$ Mo, W) were investigated by Bergstrom, and it was found that the bulkiness of the ligand $\mathrm{AsPh}_{3}$ results in a distorted octahedrons [10]. However, Fischer carbene complexes comprising arsines as ligands are still limited in literature [3,4,5,11]. Since a number of phosphine-substituted tungsten(0) Fischer alkoxycarbenes with various heteroarene substituents have been synthesized in our laboratories recently [12], we were interested to determine whether the phosphine- and arsine-substituted complexes have similar structural features. Fischer and Richter noted that the substituted complexes exhibited heightened airstability, in comparison to their parent compounds [4]. This makes the substituted complexes prime candidates for industrial applications studies. Additionally, the stereochemistry of the substituted complexes is primarily cis, thus allowing for stereoselective substitution reactions on the arsine-substituted Fischer carbene complexes. Therefore, we report here the synthesis, 
structural and theoretical study of four novel triphenylarsine-substituted Fischer ethoxycarbene complexes of the type $\operatorname{cis}$ - $\left[\left(\mathrm{AsPh}_{3}\right)(\mathrm{CO})_{4} \mathrm{WC}(\mathrm{OEt})(\mathrm{Ar})\right]$ for $\mathrm{Ar}=2$-thienyl (1), 2-furyl (2), 2-(N-methyl)pyrrolyl (3), and 2,2'-bithienyl (4). In the DFT computational study, several conformations (Schemes 1 and 2 in Supporting Information) of the novel complexes were considered to determine the lowest-energy conformer.
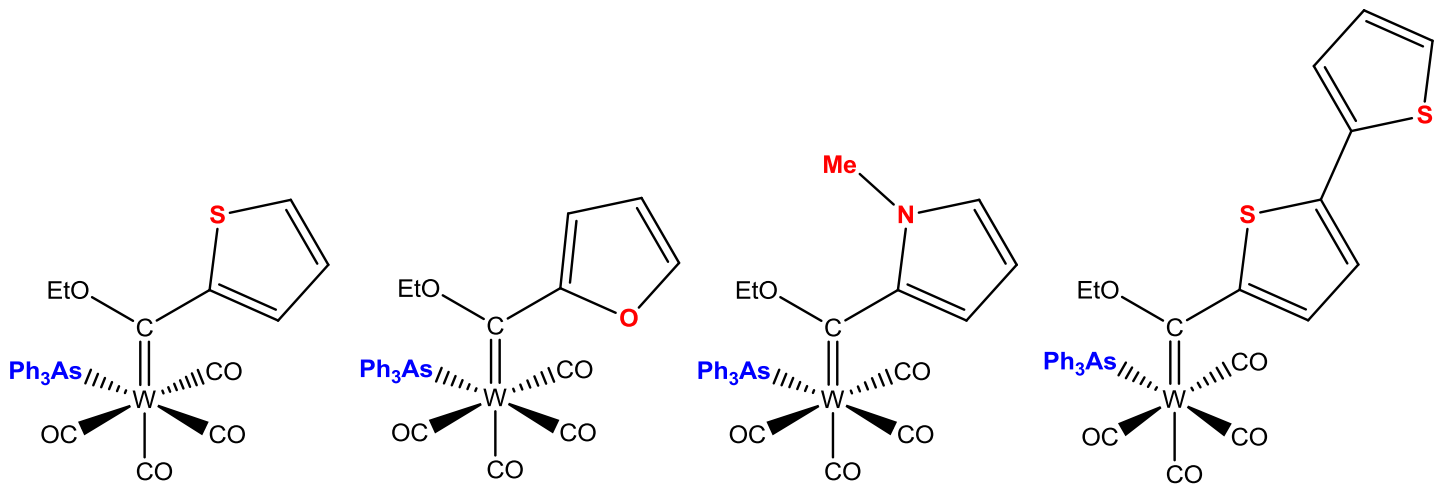

Scheme 1. Cis-isomers of the arsine-substituted Fischer ethoxycarbene complexes of tungsten(0) for the heteroarenes: thiophene (1), furan (2), N-methylpyrrole (3), and 2,2'-bithiophene (4). The position of the $\mathrm{AsPh}_{3}$ group relative to the carbene ligand (cis or trans) as well as the orientation of the aryl ring (syn or anti relative to the ethoxy group) lead to several possible conformers of $\mathbf{1}-\mathbf{4}$, see Schemes 1 and 2 of the Supplementary Information for a description of the conformers.

\section{Experimental materials and methods}

\section{$2.1 \quad$ General}

All reactions were performed under inert argon atmospheres using standard Schlenk techniques. All solvents were freshly distilled, dried and collected under inert conditions. Column chromatography was carried out under inert nitrogen and argon atmospheres using silica gel (particle size $0.063-0.200 \mathrm{~mm}$ ) as the stationary phase. Percentage yields were calculated relative to the limiting reactant. Crystallization was done using hexane-DCM diffusion methods. Commercial thiophene was purified [13] and triethyloxonium tetrafluoroborate was prepared according to a reported literature procedure [14]. The reagents [W(CO) $)_{6}$, n-butyl lithium (1.6 $\mathrm{M}$ solution in hexane), furan, $\mathrm{N}$-methylpyrrole and triphenylarsine $\left(\mathrm{AsPh}_{3}\right)$ were used as purchased. The tungsten(0) pentacarbonyl Fischer ethoxycarbene complexes for the heteroarenes thiophene, A [15], furan, B [16], Nmethylpyrrole, C [17], and 2,2'-bithiophene, D [18] were synthesized according to literature procedures. NMR spectra were recorded on a Bruker ARX-300. NMR spectra were recorded in $\mathrm{CDCl}_{3}$ using deuterated solvent peaks as the internal references. ${ }^{1} \mathrm{H}$ and ${ }^{13} \mathrm{C}$ NMR spectra were measured at 300.1 and $75.5 \mathrm{M} \mathrm{Hz}$, respectively. Numbering of atoms in the NMR 
assignment was done according to the numbering system used in Figure 2-5. Protons are assigned according to the corresponding labelled carbon atoms. IR spectra were recorded on a Perkin Elmer Spectrum RXI FT-IR spectrophotometer as KBr pellets and only the vibration bands in the carbonyl-stretching region (1500-2200 $\mathrm{cm}^{-1}$ ) are reported. Mass spectra were recorded on a SYNAPT G2 HDMS instrument with the TOF-MS method, with a sampling time of 3 minutes with direct infusion inlet method. The source was electron-spray ionisation. Melting points were recorded on a Stuart SMP10 instrument.

\subsection{Synthesis of 1-4}

2.2.1 cis-[( $\left.\left.\mathrm{AsPh}_{3}\right)(\mathrm{CO})_{4} \mathrm{WC}(\mathrm{OEt})\left(\mathrm{C}_{4} \mathrm{H}_{3} \mathrm{~S}\right)\right](\mathbf{1})$

$\left[(\mathrm{CO})_{5} \mathrm{WC}(\mathrm{OEt})\left(\mathrm{C}_{4} \mathrm{H}_{3} \mathrm{~S}\right)\right], \mathbf{A},(0.464 \mathrm{~g}, 1 \mathrm{mmol})$ and $\mathrm{AsPh}_{3}(0.337 \mathrm{~g}, 1.1 \mathrm{mmol})$ were dissolved in hexane $(40 \mathrm{~m} \ell)$, resulting in a dark red solution. The mixture was refluxed for 12 hours, during which the solution changed colour from red to brown. The solvent was removed in vacuo and the residue was purified using silica gel column chromatography, using gradient elution with hexane and dichloromethane. A red fraction was collected, corresponding to the starting material, $\mathbf{A}$, as well as a brown fraction, corresponding to $\mathbf{1}$ $(37 \%)$.

${ }^{1} \mathrm{H}-\mathrm{NMR}\left(\mathrm{CDCl}_{3}, \mathrm{ppm}\right) \delta 7.86\left(\mathrm{dd}, 1 \mathrm{H}, \mathrm{J}_{\mathrm{H}-\mathrm{H}}=4.0,1.1 \mathrm{~Hz}, \mathrm{H} 8\right), 7.57\left(\mathrm{dd}, 1 \mathrm{H}, \mathrm{J}_{\mathrm{H}-\mathrm{H}}=5.0,1.1\right.$ $\mathrm{Hz}, \mathrm{H} 10), 7.24-7.44\left(\mathrm{~m}, 15 \mathrm{H}, \mathrm{AsPh}_{3}\right), 6.91\left(\mathrm{dd}, 1 \mathrm{H}, \mathrm{J}_{\mathrm{H}-\mathrm{H}}=5.0,4.0 \mathrm{~Hz}, \mathrm{H} 9\right), 4.58$ (q, 2H, $\mathrm{J}_{\mathrm{H}-\mathrm{H}}$ $=7.0 \mathrm{~Hz}, \mathrm{H} 11), 1.17\left(\mathrm{t}, 3 \mathrm{H}, \mathrm{J}_{\mathrm{H}-\mathrm{H}}=7.0 \mathrm{~Hz}, \mathrm{H} 12\right) ;{ }^{13} \mathrm{C}-\mathrm{NMR}\left(\mathrm{CDCl}_{3}, \mathrm{ppm}\right) \delta 294.3$ (C6), 210.0 (C1), 206.8 (C3), 202.7 (C2 and C4), 159.3 (C7), 140.0 (C8), 139.6 (C20), 133.7 (C21), 132.7 (C10), 129.8 (C9), 128.9 (C22), 128.6 (C23), 77.2 (C11), 15.1 (C12); IR (KBr, $\left.v(\mathrm{CO}) / \mathrm{cm}^{-1}\right) 2009\left(A_{1}^{1}\right), 1928\left(A_{1}^{2}\right), 1898\left(\mathrm{~B}_{1}\right), 1878\left(\mathrm{~B}_{2}\right)$; MS (m/z): Calc. 726.251 [M], Exp. $727.0[\mathrm{M}+1]^{+}$; m.p. $118-120^{\circ} \mathrm{C}(\mathrm{dec})$.

\subsection{2 cis-[( $\left.\left.\mathrm{AsPh}_{3}\right)(\mathrm{CO})_{4} \mathrm{WC}(\mathrm{OEt})\left(\mathrm{C}_{4} \mathrm{H}_{3} \mathrm{O}\right)\right](2)$}

$\left[(\mathrm{CO})_{5} \mathrm{WC}(\mathrm{OEt})\left(\mathrm{C}_{4} \mathrm{H}_{3} \mathrm{O}\right)\right], \mathbf{B},(0.448 \mathrm{~g}, 1 \mathrm{mmol})$ and $\mathrm{AsPh}_{3}(0.337 \mathrm{~g}, 1.1 \mathrm{mmol})$ were dissolved in hexane $(40 \mathrm{~m} \ell)$, resulting in a dark red solution. The mixture was refluxed for 12 hours, during which time the solution changed colour from red to brown. The solvent was removed in vacuo, and the residue was purified using silica gel column chromatography, using gradient elution with hexane and dichloromethane. A red fraction was collected, corresponding to the starting material, $\mathbf{B}$ as well as a brown fraction, corresponding to $\mathbf{2}$ $(48 \%)$. 
${ }^{1} \mathrm{H}-\mathrm{NMR}\left(\mathrm{CDCl}_{3}, \mathrm{ppm}\right) \delta 7.32\left(\mathrm{~d}, 1 \mathrm{H}, \mathrm{J}_{\mathrm{H}-\mathrm{H}}=1.0 \mathrm{~Hz}, \mathrm{H} 10\right), 7.22-7.41\left(\mathrm{~m}, 15 \mathrm{H}, \mathrm{AsPh}_{3}\right), 7.20$ $\left(\mathrm{dd}, 1 \mathrm{H}, \mathrm{J}_{\mathrm{H}-\mathrm{H}}=1.7,0.8 \mathrm{~Hz}, \mathrm{H} 8\right), 6.72\left(\mathrm{dd}, 1 \mathrm{H}, \mathrm{J}_{\mathrm{H}-\mathrm{H}}=3.6,0.8 \mathrm{~Hz}, \mathrm{H} 9\right), 4.78\left(\mathrm{q}, 2 \mathrm{H}, \mathrm{J}_{\mathrm{H}-\mathrm{H}}=7.1\right.$ $\mathrm{Hz}, \mathrm{H} 11), 1.39$ (t, 3H, J-H $=7.1 \mathrm{~Hz}, \mathrm{H} 12) ;{ }^{13} \mathrm{C}-\mathrm{NMR}\left(\mathrm{CDCl}_{3}, \mathrm{ppm}\right) \delta 289.0$ (C6), 211.0 (C1), 207.1 (C3), 202.7 (C2 and C4), 166.5 (C7), 147.8 (C10), 139.6 (C20), 133.7 (C21), 129.6 (C22), 128.6 (C23), 112.7 (C8), 111.0 (C9), 77.0 (C11) 15.0 (C12); IR (KBr, $\left.v(\mathrm{CO}) / \mathrm{cm}^{-1}\right): 2011\left(A_{1}^{1}\right), 1921\left(A_{1}^{2}\right), 1892\left(\mathrm{~B}_{1}\right), 1862\left(\mathrm{~B}_{2}\right) ; \mathrm{MS}(\mathrm{m} / \mathrm{z})$ : Calc. 742.318 [M], Exp. $743.0[\mathrm{M}+1]^{+}$; m.p. $131-132^{\circ} \mathrm{C}(\mathrm{dec})$.

\subsection{3 cis-[( $\left.\left.\mathrm{AsPh}_{3}\right)(\mathrm{CO})_{4} \mathrm{WC}(\mathrm{OEt})\left(\mathrm{C}_{4} \mathrm{H}_{3} \mathrm{NMe}\right)\right](3)$}

$\left[(\mathrm{CO})_{5} \mathrm{WC}(\mathrm{OEt})\left(\mathrm{C}_{4} \mathrm{H}_{3} \mathrm{NMe}\right)\right], \mathbf{C},(0.461 \mathrm{~g}, 1 \mathrm{mmol})$ and $\mathrm{AsPh}_{3}(0.337 \mathrm{~g}, 1.1 \mathrm{mmol})$ were dissolved in hexane $(40 \mathrm{~m} \ell)$, resulting in an orange solution. The mixture was refluxed for 12 hours, during which time the solution changed colour from orange to orange-red. The solvent was removed in vacuo, and the residue was purified using silica gel column chromatography, using gradient elution with hexane and dichloromethane. An orange fraction was collected, corresponding to the starting material, $\mathbf{C}$, as well as a red fraction, corresponding to $\mathbf{3}(58 \%)$. ${ }^{1} \mathrm{H}-\mathrm{NMR}\left(\mathrm{CDCl}_{3}, \mathrm{ppm}\right) \delta 7.66\left(\mathrm{dd}, 1 \mathrm{H}, \mathrm{J}_{\mathrm{H}-\mathrm{H}}=4.6 \mathrm{~Hz}, 1.8 \mathrm{~Hz}, \mathrm{H} 8\right), 7.16-7.43(\mathrm{~m}, 15 \mathrm{H}$, $\left.\mathrm{AsPh}_{3}\right), 6.90$ (s(br), 1H, H10), $6.26\left(\mathrm{dd}, 1 \mathrm{H}, \mathrm{J}_{\mathrm{H}-\mathrm{H}}=4.5,2.3 \mathrm{~Hz}, \mathrm{H} 9\right), 4.93$ (q, 2H, J $\mathrm{H}_{\mathrm{H}-\mathrm{H}}=7.1$ $\mathrm{Hz}, \mathrm{H} 11), 3.78$ (s(br), 3H, H13), 1.33 (t, 3H, J $\left.\mathrm{J}_{\mathrm{H}}=7.1 \mathrm{~Hz}, \mathrm{H} 12\right) ;{ }^{13} \mathrm{C}-\mathrm{NMR}\left(\mathrm{CDCl}_{3}, \mathrm{ppm}\right) \delta$ 297.5 (C6), 211.0 (C1), 205.6 (C3), 204.1 (C2 and C4), 143.4 (C7), 139.6 (C20), 134.9 (C8), 133.7 (C21), 132.4 (C10), 128.7 (C22) 128.5 (C23), 111.2 (C9), 77.4 (C11), 40.7 (C13), 15.2 (C12); IR (KBr, $\left.v(\mathrm{CO}) / \mathrm{cm}^{-1}\right) 2006\left(A_{1}^{1}\right), 1917\left(A_{1}^{2}\right), 1897\left(\mathrm{~B}_{1}\right), 1886\left(\mathrm{~B}_{2}\right) ; \mathrm{MS}(\mathrm{m} / \mathrm{z})$ : Calc. $739.293[\mathrm{M}]$, Exp. $740.0[\mathrm{M}+1]^{+}$; m.p. $161-163^{\circ} \mathrm{C}(\mathrm{dec})$.

\subsection{4 cis-[( $\left.\left.\mathrm{AsPh}_{3}\right)(\mathrm{CO})_{4} \mathrm{WC}(\mathrm{OEt})\left(\mathrm{C}_{8} \mathrm{H}_{5} \mathrm{~S}_{2}\right)\right](\mathbf{4})$}

$\left[(\mathrm{CO})_{5} \mathrm{WC}(\mathrm{OEt})\left(\mathrm{C}_{8} \mathrm{H}_{5} \mathrm{~S}_{2}\right)\right], \mathbf{D},(0.458 \mathrm{~g}, 1 \mathrm{mmol})$ and $\mathrm{AsPh}_{3}(0.337 \mathrm{~g}, 1.1 \mathrm{mmol})$ were dissolved in hexane $(40 \mathrm{~m} \ell)$, resulting in a dark red solution. The mixture was refluxed for 12 hours, during which time the solution changed colour from red to purple-brown. The solvent was removed in vacuo, and the residue was purified using silica gel column chromatography, using gradient elution with hexane and dichloromethane. A red fraction was collected, corresponding to the starting material, $\mathbf{D}$ as well as a purple fraction, corresponding to $\mathbf{4}$ $(52 \%)$.

${ }^{1} \mathrm{H}-\mathrm{NMR}\left(\mathrm{CDCl}_{3}\right.$, ppm) $\delta$ 7.34-7.43 (m, 15H, AsPh $\mathbf{3}_{3}$ ) 7.21-7.26 (m, 1H, H17), 7.04-7.09 (m, $1 \mathrm{H}, \mathrm{H} 16), 7.30-7.33(\mathrm{~m}, 1 \mathrm{H}, \mathrm{H} 15), 7.01\left(\mathrm{~d}, 1 \mathrm{H}, \mathrm{J}_{\mathrm{H}-\mathrm{H}}=4.3 \mathrm{~Hz}, \mathrm{H} 9\right), 7.79\left(\mathrm{~d}, 1 \mathrm{H}, \mathrm{J}_{\mathrm{H}-\mathrm{H}}=4.3\right.$ 
$\mathrm{Hz}, \mathrm{H} 8) 4.62\left(\mathrm{q}, 2 \mathrm{H}, \mathrm{J}_{\mathrm{H}-\mathrm{H}}=7.0 \mathrm{~Hz}, \mathrm{H} 11\right), 1.24$ (t, 3H, $\left.\mathrm{J}_{\mathrm{H}-\mathrm{H}}=7.0 \mathrm{~Hz}, \mathrm{H} 12\right) ;{ }^{13} \mathrm{C}-\mathrm{NMR}\left(\mathrm{CDCl}_{3}\right.$, ppm) $\delta 272.1$ (C6), 210.0 (C1), 202.9 (C2 and C4), 207.0 (C3), 125.4 (C7), 128.4 (C8), 124.7 (C9), 137.1 (C10), 136.3 (C14), 124.3 (C15), 128.3 (C16), 125.2 (C17), 77.2 (C11) 14.7 (C12), 139.6 (C20), 133.8 (C21), 128.9 (C22) 128.5 (C23); IR (KBr, v(CO)/cm $\left.{ }^{-1}\right) 2011\left(A_{1}^{1}\right)$, $1918\left(A_{1}^{2}\right), 1895\left(\mathrm{~B}_{1}\right), 1879\left(\mathrm{~B}_{2}\right)$; MS (m/z): Calc. 824.442 [M], Exp. $825.0[\mathrm{M}+1]^{+}$; m.p. 149 $-150^{\circ} \mathrm{C}(\mathrm{dec})$.

\subsection{DFT calculations}

Density functional theory (DFT) calculations of this study were performed with the hybrid functional B3LYP [19,20] (20\% Hartree-Fock exchange) [21], the dispersion corrected B3LYP-D3 [22] and the M06 [23] functional, as implemented in the Gaussian 09 program package [24]. Geometries of the neutral complexes were optimized in gas phase with the triple- $\zeta$ basis set 6-311G(d,p) on all atoms except $\mathrm{W}$, where def2-TZVPP [25] was used. Energies reported are gas phase electronic energies.

\subsection{X-ray Crystallography}

Crystals suitable for single crystal X-ray crystallography were obtained for 1-4. Crystal data were collected at $150 \mathrm{~K}$ on a Bruker D8 Venture kappa geometry diffractometer with duo I $\mu \mathrm{s}$ sources, a Photon 100 CMOS detector and APEX II [26] control software using Quazar multi-layer optics monochromated, Mo-Ka radiation by means of a combination of $\phi$ and $\omega$ scans. Data reduction was performed using SAINT+ [26] and the intensities were corrected for absorption using SADABS [26]. The structures were solved by intrinsic phasing using SHELXTS [27] and refined by full-matrix least squares using SHELXTL and SHELXL97/2013/2014 [27]. In the structure refinement, all hydrogen atoms attached to carbon atoms were added in calculated positions and treated as riding on the atom to which they are attached. All non-hydrogen atoms were refined with anisotropic displacement parameters, all isotropic displacement parameters for hydrogen atoms were calculated as $\mathrm{X} \times \mathrm{Ueq}$ of the atom to which they are attached, $X=1.5$ for the methyl hydrogens and 1.2 for all other hydrogens. Crystal data, data collection, structure solution and refinement details are available in each CIF. ORTEP drawings [28] of the structures are included in Figure 2-5, showing the numbering system used with ADP's at the 50\% probability level. 


\section{Results and Discussion}

\subsection{Synthesis}

The synthesis of substituted Fischer alkoxycarbene complexes can be done using one of two methods [3-12], as depicted in Scheme 2. Ligand substitution of a carbonyl with a tertiary phosphine group before or after carbene formation lead to exclusively cis or a mixture of cis and trans product isomers respectively.

a.<smiles></smiles>

b.<smiles></smiles>

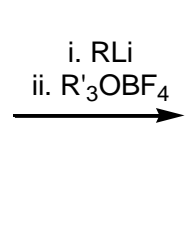

$\underset{\Delta \text { or } h v}{\stackrel{\mathrm{ER}_{3}}{\longrightarrow}}$<smiles></smiles>
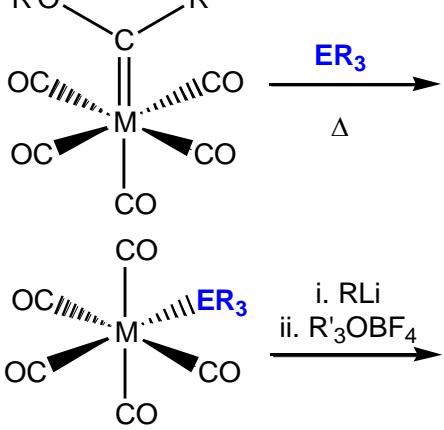<smiles></smiles><smiles></smiles><smiles></smiles>

$\mathrm{R}=\mathrm{Alkyl} / \mathrm{Aryl}$

$\mathrm{R}^{\prime}=\mathrm{Me}$ or Et $\mathrm{E}=$ As or $\mathrm{P}$ $\mathrm{M}=\mathrm{Cr}, \mathrm{Mo}$, or $\mathrm{W}$

Scheme 2. Two methods for the synthesis of substituted Fischer carbene complexes [3-12]

The method shown in Scheme 2(a) [12] was employed in the synthesis of complexes 1-4. Hexane was used as solvent [4]. The formation of the product complex as either a brown, purple or red-orange spot was observed on thin layer chromatography (TLC). Although toluene (with a higher boiling point) as solvent was successfully used in the synthesis of phosphine- and phosphite-substituted tetracarbonyl Fischer ethoxycarbene complexes of tungsten(0) [12], test reactions using toluene as solvent in the synthesis of 1-4 led to a decomposition product. Using hexane over toluene has the further advantage that the starting materials are soluble in hexane, yet the product is not. The product precipitated of the out of the hexane solution. The fact that a lower boiling-point solvent yielded a substitution product through thermolysis may be indicative of the thermal stability of the substituted complexes. The phosphine- substituted tetracarbonyl Fischer ethoxycarbene complexes of tungsten(0) may be stable at higher temperatures [12], whilst the arsine-substituted analogues are not.

When using the pentacarbonyl Fischer ethoxycarbene complex as starting complex (route in Scheme 2(a)), two structural isomers (cis and trans) are theoretically possible [4]. However, only one product, the $c i s$-isomer, was isolated. This result was also obtained by Werner and 
Rascher in the synthesis of $\left[\left(\mathrm{PR}_{3}\right)(\mathrm{CO})_{4} \mathrm{CrC}(\mathrm{OMe})(\mathrm{Me})\right][11]$, as well as by Fischer and Fischer for $\left[\left(\mathrm{PR}_{3}\right)(\mathrm{CO})_{5} \mathrm{MC}\left(\mathrm{OR}^{\prime}\right)(\mathrm{Y})\right]$ with $\mathrm{M}=\mathrm{Cr}, \mathrm{W}$; R' = Me, Et; Y = Me, Et, ${ }^{i} \mathrm{Pr}, \mathrm{Ph}[29]$. Since Fischer carbene ligands and phosphine-ligands have similar electron withdrawing effects [11], it is electronically unfavourable to have both these ligands trans to one another [11]. It would thus be electronically more stable to have a CO trans to the highly electrophilic carbene [1] and a CO trans to the phosphine-ligand. Thus, in the cis-isomer of the phosphinesubstituted Fischer carbene complexes, the ligands are arranged so that the electrophilicity of the carbene carbon is stabilised through back-donation of electron density from the CO trans from the carbene ligand. The same applies to the arsine-substituted complexes.

It has previously been reported that the trans-isomer can be separated and isolated from the cis-isomer, for the phosphine-substituted Fischer ethoxy carbene tungsten (0) complexes [12]. This is not the case for the arsine-substituted analogues. Even though two products, the cissubstituted $\mathrm{AsPh}_{3}$ product and a decomposition product, as well as some unreacted starting material were observed on TLC, only one product was collected from column chromatography.

\subsection{Characterization}

Complexes 1-4 were characterised using ${ }^{1} \mathrm{H}$ and ${ }^{13} \mathrm{C}$ NMR spectroscopy, IR spectroscopy, electrospray-ionisation mass spectrometry, melting point determination, as well as singlecrystal X-ray diffraction. On the ${ }^{1} \mathrm{H}-\mathrm{NMR}$ in $\mathrm{CDCl}_{3}$, the heteroarene protons peaks for $\mathbf{1}, \mathbf{2}$, and 3 were well resolved. For complex 4, the heteroarene proton peaks were assigned as multiplets. This is due to the extensive proton-proton coupling that can occur in the 2,2'bithienyl-group. The aromatic peaks of the phenyl-rings on the triphenylarsine ligand were observed as multiplets for all four complexes.

On the ${ }^{13} \mathrm{C}-\mathrm{NMR}$ spectra, the characteristic carbene carbon peak was observed for all four complexes in the region of 270-300 ppm, as shown in Table 1. The carbene carbon was shifted upfield for 2 and $\mathbf{4}$ (10-20 ppm) and downfield for $\mathbf{1}$ and $\mathbf{3}$ (1-14 ppm) relative to the shift in the related un-substituted $\left[(\mathrm{CO})_{5} \mathrm{WC}(\mathrm{OEt})(\mathrm{R})\right]$ complexes. The carbene peak chemical shifts (ppm) of the triphenylphosphine analogues for $\mathbf{1}$ and $\mathbf{2}$ [12] are similar to the values observed, see Table 1. 
Table 1. Carbene carbon (C6) peaks (ppm) for the reagent and substituted complexes

\begin{tabular}{cccc}
\hline & & \\
Carbene peak \\
(ppm)
\end{tabular}

Three carbonyl carbon peaks, corresponding to $\mathrm{C} 1$ (trans to carbene C6), $\mathrm{C} 3$ (trans to $\mathrm{AsPh}_{3}$ ) and C2/C4 (trans to each other) were observed in the carbonyl-region (200-230 ppm) of each of the novel complexes. This is the characteristic pattern for cis-tetracarbonyl ligands $[4,12,11]$ with a peak height ratio of 1:1:2 [12,11]. The chemical shift for the carbonyl carbons is influenced by the ligand that is trans to that carbonyl ligand. The literature trend for the chemical shift of carbonyl ligand trans to ligand $\mathrm{L}$, is as follows: $\mathrm{L}=$ carbonyl $<$ arsine $<$ phosphine < carbene [31]. Thus, the carbonyl trans to the carbene $(\mathrm{C} 1)$ will have be the most downfield shifted carbonyl carbon-peak. The next most downfield-shifted carbonyl carbon-peak would represent the carbonyl ligand that is trans to the arsine ligand (C3). The last carbonyl carbon-peak with double the peak height, represents the two carbonyl ligands that are trans to one another ( $\mathrm{C} 2$ and $\mathrm{C} 4)$. This trend varies primarily according to the donor ability of the ligand [31].

In Table 2 the carbonyl IR data of 1-4 are compared to related complexes. The carbonyl bands for all of the arsine-complexes are found at similar wavenumbers than their corresponding phosphine- and phosphite analogues. This trend is unexpected, as one would expect the carbonyl stretching frequencies for the complexes containing weaker $\pi$-acceptor ligands $\left(\mathrm{AsPh}_{3}\right)$ to have lower values compared to their phosphine analogues. This observation, however, was also reported for $\left[\mathrm{EPh}_{3}(\mathrm{CO})_{5} \mathrm{~W}\right](\mathrm{E}=\mathrm{P}$, As) [32] and cis$\left[\mathrm{EPh}_{3}(\mathrm{CO})_{4} \mathrm{WC}(\mathrm{OMe})(\mathrm{Me})\right](\mathrm{E}=\mathrm{P}, \mathrm{As})[3]$, see Table 2. Results in Table 2 show that the Rgroups and identity of $\mathrm{E}$ in $\mathrm{ER}_{3}(\mathrm{E}=\mathrm{P}, \mathrm{As} ; \mathrm{R}=$ alkyl, aryl or $\mathrm{OPh})$ does not have a significant influence on the position of the $\mathrm{A}^{1}{ }_{1}$ or $\mathrm{A}^{1}{ }_{2} \mathrm{CO}$ stretching frequencies in W-Fischer carbene complexes containing an OR' $\left(\mathrm{R}^{\prime}=\mathrm{Me}, \mathrm{Et}\right)$ carbene substituent. 
Table 2. Selected IR stretching frequencies $\left(\mathrm{cm}^{-1}\right)$ of $\mathbf{1}-\mathbf{4}$, compared with phosphine and other literature analogues

\begin{tabular}{|c|c|c|c|c|c|}
\hline & $\mathbf{A}_{1}{ }^{1}$ & $\mathbf{A}_{1}{ }^{2}$ & $\mathbf{B}_{1}$ & $\mathbf{B}_{2}$ & Reference \\
\hline $\mathbf{1}$, cis $-\left[(\mathrm{CO})_{4}\left(\mathrm{AsPh}_{3}\right) \mathrm{WC}(\mathrm{OEt})\left(\mathrm{C}_{4} \mathrm{H}_{3} \mathrm{~S}\right)\right]^{\mathrm{a}}$ & 2009 & 1928 & 1898 & 1878 & This work \\
\hline 2, cis- $\left[(\mathrm{CO})_{4}\left(\mathrm{AsPh}_{3}\right) \mathrm{WC}(\mathrm{OEt})\left(\mathrm{C}_{4} \mathrm{H}_{3} \mathrm{O}\right)\right]^{\mathrm{a}}$ & 2011 & 1921 & 1892 & 1862 & This work \\
\hline 3, cis- $\left[(\mathrm{CO})_{4}\left(\mathrm{AsPh}_{3}\right) \mathrm{WC}(\mathrm{OEt})\left(\mathrm{C}_{4} \mathrm{H}_{3} \mathrm{NMe}\right)\right]^{\mathrm{a}}$ & 2006 & 1917 & 1897 & 1886 & This work \\
\hline 4, cis- $\left[(\mathrm{CO})_{4}\left(\mathrm{AsPh}_{3}\right) \mathrm{WC}(\mathrm{OEt})\left(\mathrm{C}_{8} \mathrm{H}_{5} \mathrm{~S}\right)\right]^{\mathrm{a}}$ & 2011 & 1918 & 1895 & 1879 & This work \\
\hline $\operatorname{cis}-\left[(\mathrm{CO})_{4}\left(\mathrm{PPh}_{3}\right) \mathrm{WC}(\mathrm{OEt})\left(\mathrm{C}_{4} \mathrm{H}_{3} \mathrm{~S}\right)\right]^{\mathrm{b}}$ & 2009 & 1914 & 1894 & 1883 & {$[12]$} \\
\hline $\operatorname{cis}-\left[(\mathrm{CO})_{4}\left(\mathrm{PPh}_{3}\right) \mathrm{WC}(\mathrm{OEt})\left(\mathrm{C}_{4} \mathrm{H}_{3} \mathrm{O}\right)\right]^{\mathrm{b}}$ & 2009 & 1921 & 1888 & 1860 & [12] \\
\hline $\operatorname{cis}-\left[(\mathrm{CO})_{4}\left(\mathrm{P}(\mathrm{OPh})_{3}\right) \mathrm{WC}(\mathrm{OEt})\left(\mathrm{C}_{4} \mathrm{H}_{3} \mathrm{~S}\right)\right]^{\mathrm{b}}$ & 1996 & 1917 & 1889 & $1889^{\mathrm{c}}$ & [12] \\
\hline $\operatorname{cis}-\left[(\mathrm{CO})_{4}\left(\mathrm{P}(\mathrm{OPh})_{3}\right) \mathrm{WC}(\mathrm{OEt})\left(\mathrm{C}_{4} \mathrm{H}_{3} \mathrm{O}\right)\right]^{\mathrm{b}}$ & 2000 & 1918 & 1893 & $1893^{\mathrm{c}}$ & [12] \\
\hline $\operatorname{cis}-\left[(\mathrm{CO})_{4}\left(\mathrm{PPh}_{3}\right) \mathrm{WC}(\mathrm{OMe})(\mathrm{Me})\right]^{\mathrm{b}}$ & 2024 & 1925 & 1914 & 1897 & {$[3]$} \\
\hline $\operatorname{cis}-\left[(\mathrm{CO})_{4}\left(\mathrm{AsPh}_{3}\right) \mathrm{WC}(\mathrm{OMe})(\mathrm{Me})\right]^{\mathrm{b}}$ & 2022 & 1927 & 1912 & 1921 & [3] \\
\hline
\end{tabular}

${ }^{\mathrm{a}} \mathrm{KBr}$ matrix

${ }^{\mathrm{b}}$ Hexane matrix

${ }^{\mathrm{c}}$ Overlapping bands

\subsection{X-ray Crystallography}

Crystals suitable for single-crystal x-ray diffraction for all four complexes were grown through vapour diffusion methods, using dichloromethane and hexane solutions (1:1). Molecular structures of 1-4 are shown in Figure 2 - 5. Selected bond lengths, bond angles and dihedral angles for 1-4 are given in Table 3 and comparative crystallographic data of 2 with its pentacarbonyl and phosphine-analogue is given in Table 4 . The complexes $\mathbf{1}-\mathbf{4}$ crystallize in centrosymmetric space groups: P21/n, P21/c, P21/n and P-1, respectively. The unit cell of 1-3 contains four crystals (two identical crystals plus their 2 enantiomers), while the unit cell of $\mathbf{4}$ contains two crystals (one crystal plus the enantiomers).

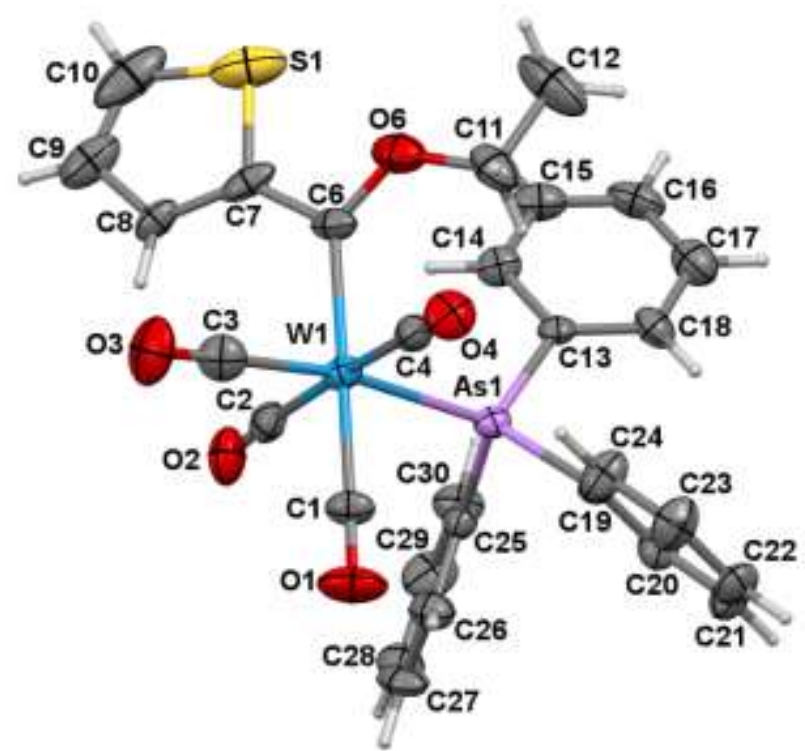

Figure 2. Perspective view of 1 (cis-syn (2) conformer) with thermal ellipsoids drawn at the $50 \%$ probability level. 


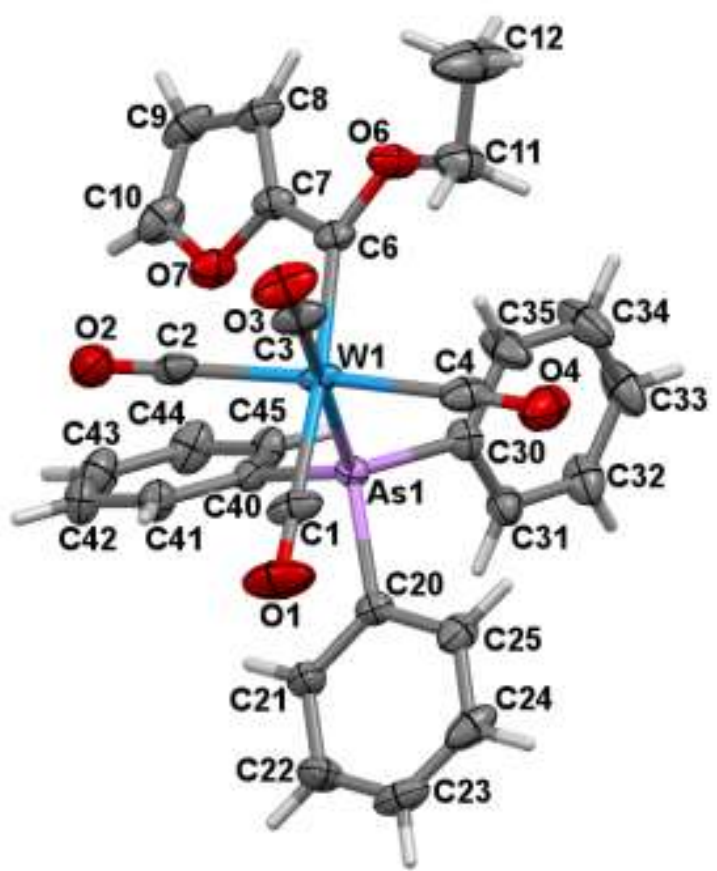

Figure 3. Perspective view of $\mathbf{2}$ (cis-anti (1) conformer) with thermal ellipsoids drawn at the 50\% probability level.

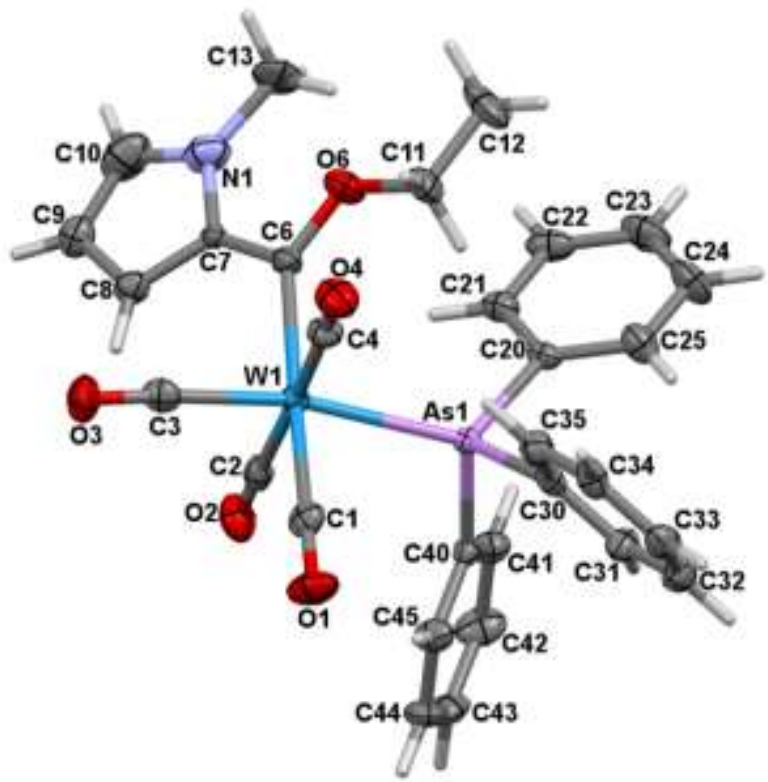

Figure 4. Perspective view of $\mathbf{3}$ (cis-syn (2) conformer) with thermal ellipsoids drawn at the $50 \%$ probability level. 


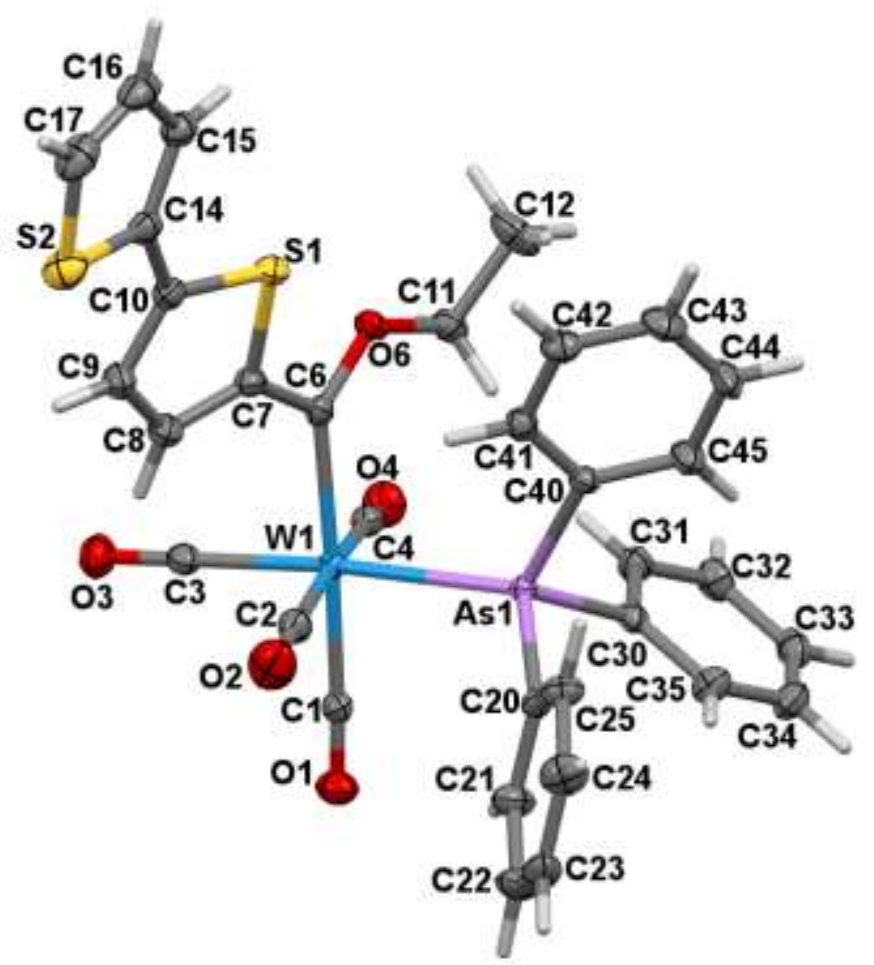

Figure 5. Perspective view of 4 (cis-syn-anti (2) conformer) with thermal ellipsoids drawn at the 50\% probability level.

Table 3. Selected bond lengths $(\AA)$, bond angles $\left(^{\circ}\right)$ and dihedral angles $\left(^{\circ}\right)$ for 1-4.

\begin{tabular}{|c|c|c|c|c|}
\hline & 1 & 2 & 3 & 4 \\
\hline \multicolumn{5}{|l|}{ Bond length $(\AA)$} \\
\hline W1-C6 & $2.177(7)$ & $2.178(3)$ & $2.225(5)$ & $2.192(3)$ \\
\hline W1-C1 & $2.008(7)$ & $2.017(4)$ & $1.996(5)$ & $2.023(3)$ \\
\hline W1-C2 & $2.038(9)$ & $2.030(4)$ & $2.030(5)$ & $2.040(3)$ \\
\hline W1-C3 & $1.978(9)$ & $1.978(4)$ & $1.979(5)$ & $2.006(3)$ \\
\hline W1-C4 & $2.040(9)$ & $2.040(4)$ & $2.035(5)$ & $2.060(3)$ \\
\hline W1-As1 & $2.6240(8)$ & $2.6282(4)$ & $2.6313(5)$ & $2.6635(6)$ \\
\hline $\mathrm{C} 1-\mathrm{O} 1$ & $1.137(9)$ & $1.147(4)$ & $1.158(6)$ & $1.161(3)$ \\
\hline $\mathrm{C} 2-\mathrm{O} 2$ & $1.139(10)$ & $1.150(4)$ & $1.145(6)$ & $1.155(4)$ \\
\hline $\mathrm{C} 3-\mathrm{O} 3$ & $1.153(11)$ & $1.153(4)$ & $1.157(6)$ & $1.151(4)$ \\
\hline $\mathrm{C} 4-\mathrm{O} 4$ & $1.135(10)$ & $1.144(5)$ & $1.142(6)$ & $1.153(4)$ \\
\hline C6-C7 & $1.457(12)$ & $1.447(5)$ & $1.430(7)$ & $1.476(4)$ \\
\hline C6-O6 & $1.345(10)$ & $1.330(4)$ & $1.349(6)$ & $1.341(3)$ \\
\hline \multicolumn{5}{|l|}{ Bond angle $\left(^{\circ}\right)$} \\
\hline As1-W1-C6 & $97.3(2)$ & $92.62(8)$ & $96.23(12)$ & $93.80(7)$ \\
\hline C7-C6-O6 (A) ${ }^{\mathrm{b}}$ & $106.6(6)$ & $104.6(3)$ & $108.1(4)$ & $105.2(2)$ \\
\hline W1-C6-C7 (B) ${ }^{\mathrm{b}}$ & $123.6(6)$ & $124.4(2)$ & $123.7(3)$ & $124.04(19)$ \\
\hline W1-C6-O6 (C) & $129.7(6)$ & $130.9(2)$ & $128.2(4)$ & $130.7(2)$ \\
\hline
\end{tabular}

Dihedral angle $\left({ }^{\circ}\right)$ 


$\begin{array}{ccccc}\text { O6-C6-C7-X } & 9.4(9) & 174.2(3) & 6.1(7) & -17.7(3) \\ \text { C7-C8-C9-C10 } & 0.2(11) & -0.6(4) & 1.2(6) & -0.9(4) \\ \text { S1-C10-C14-S2 } & - & - & - & -162.21(16) \\ \text { C14-C15-C16-C17 } & - & - & - & -0.3(4)\end{array}$

${ }^{\mathrm{a}} \mathrm{X}=\mathrm{S} 1(\mathbf{1}), \mathrm{X}=\mathrm{O} 7(\mathbf{2}), \mathrm{X}=\mathrm{N} 1(3), \mathrm{X}=\mathrm{S} 1(\mathbf{4})$

${ }^{\mathrm{b}}$ Angles A, B and C are highlighted in Figure 6.

From the crystallographic data for complexes 1-4 in Table 3, it can be seen that the tungsten(0)-carbene bond (W1-C6) is relatively similar for the four complexes, with an average value of 2.193(5) $\AA$. The carbonyl trans to the triphenylarsine ligand has the shortest W-C bond, the average value being 1.985(5) $\AA$, while the carbonyl trans to another carbonyl has the longest W-C bond length, with an average value of 2.035(5) $\AA$. The trend $\mathrm{d}(\mathrm{W}-\mathrm{C} 3)$ (trans to $\left.\mathrm{AsPh}_{3}\right)<\mathrm{d}(\mathrm{W}-\mathrm{C} 2 / \mathrm{C} 4)$ (trans $\mathrm{CO}$ ), is in agreement with the trans influence found for ligands in tungsten(0) carbonyl complexes: (largest trans-influence, longest trans bond [33]) carbonyl > arsine [32]. No trend is observed for the C-O bond lengths.

The longest bond in the complexes, the W-As bond, with an average length of 2.6368(6) $\AA$, compares well with $\mathrm{W}$-As bonds in $\mathrm{W}-\mathrm{AsPh}_{3}$ complexes, average $2.63 \AA$ [34]. The $\mathrm{W}$-As bond in 1-4 increases as the aryl group on the carbene ligand increases in size. For $\mathbf{4}$, with the largest heteroaryl substituent, the W-As bond is the longest at 2.6635(6) $\AA$ and for 3, with the bulky methyl-group on the nitrogen atom of the heteroarene ring, the W-As bond length is

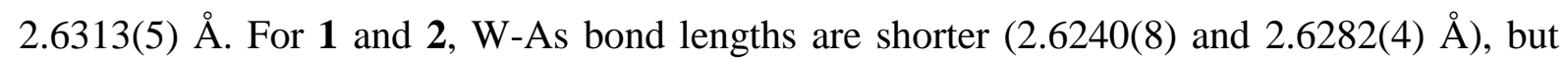
longer than in [W(CO) $)_{5} \mathrm{AsPh}_{3}$ ] (2.617 $\AA$ ) [35]. Hambley et al. [35] reported a comprehensive structural study of complexes with general formula $\left[\mathrm{M}(\mathrm{CO})_{5} \mathrm{EPh}_{3}\right]$ with $\mathrm{M}=\mathrm{Cr}, \mathrm{Mo}, \mathrm{W}$ and $\mathrm{E}=\mathrm{P}, \mathrm{As}, \mathrm{Sb}$ in order to correlate structural parameters with steric properties and $\pi$-acceptor ability of the ligand $\mathrm{EPh}_{3}$. Although the influence of the additional carbene ligand in our complexes has a marked effect on the numerical value of the parameters, the trends observed in their study and this report are strikingly similar.

The carbene carbon in Fischer carbene complexes is $\mathrm{sp}^{2}$-hybridised, and is thus expected to have trigonal planar geometry. In Figure 6 the three bond angles around the carbene carbon are assigned A, B and C. From the crystallographic data for all four complexes, bond angle A $\left(106.1(4)^{\circ}\right.$ av) is significantly smaller than B (123.9(3) ${ }^{\circ}$ av) and $C\left(129.9(4)^{\circ}\right.$ av) (Figure 6). This is due to the steric hindrances introduced by the metal centre and its ligands. The largest angle is $\mathrm{C}$ where the considerably large triphenylarsine ligand is cis with the carbene ligand. 


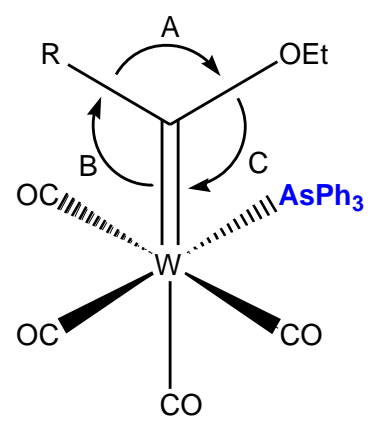

Figure 6. Three bond angles around the carbene carbon in 1-4, indicated by A, B, and C.

$\mathrm{R}=$ 2-thienyl (1), R = 2-furyl (2), R = 2-(N-methyl)pyrrolyl (3) and R = 2,2'-bithienyl (4).

One of the major structural differences between complexes 1-4 is the orientation of the furylring in 2. For the other three complexes, the heteroarene ring heteroatom $(\mathrm{X})$ is syn to the ethoxy oxygen atom (O6), where the dihedral angles are close to $0^{\circ}$ for (O6-C6-C7-X). For 2 the orientation is anti, as indicated by a dihedral angle of $174.2(3)^{\circ}$. Further, 3 has a dihedral angle of $-17.7(3)^{\circ}$, indicating some deviation from the expected $0^{\circ}[36,37]$. This may be due to the presence of the bulky methyl-group on the $\mathrm{N}$ atom of the 2-(N-methyl)pyrrolyl substituent.

The heteroaryl rings in all four complexes are planar with dihedral angle C7-C8-C9-C10 values very close to $0^{\circ}$. This too is the case for the second thienyl ring in $\mathbf{4}$, having a dihedral angle of $-0.3(4)^{\circ}$ for $\mathrm{C} 14-\mathrm{C} 15-\mathrm{C} 16-\mathrm{C} 17$. For 4 the two thienyl rings are not in the same plane, as the dihedral angle S1-C10-C14-S2 has a value of $-162.21(16)^{\circ}$. This value also indicates that the two thienyl rings are in an anti-conformation.

When comparing the structural data of cis-[( $\left.\left.\mathrm{AsPh}_{3}\right)(\mathrm{CO})_{4} \mathrm{WC}(\mathrm{OEt})\left(\mathrm{C}_{4} \mathrm{H}_{3} \mathrm{O}\right)\right]$, 2, with cis$\left[\left(\mathrm{PPh}_{3}\right)(\mathrm{CO})_{4} \mathrm{WC}(\mathrm{OEt})\left(\mathrm{C}_{4} \mathrm{H}_{3} \mathrm{O}\right)\right]$ [12] and $\left[(\mathrm{CO})_{5} \mathrm{WC}(\mathrm{OEt})\left(\mathrm{C}_{4} \mathrm{H}_{3} \mathrm{O}\right)\right]$ [38], it is evident that both 2 and its phosphine-analogue are structurally very similar; see selected data in Table 4. The only major difference is the W-E bond length, which is shorter for the phosphinecomplex than for the arsine-complex [12]. This trend is supported by literature reports for the structures of $\left[\mathrm{W}(\mathrm{CO})_{5}\left(\mathrm{EPh}_{3}\right)\right], \mathrm{E}=\mathrm{P}$ and $\mathrm{As}$ [35], where W-E bond length increased with an increase in donor atom size $(\mathrm{P}<\mathrm{As})$. The $\mathrm{W}-\mathrm{C} 3$ bond trans to $\mathrm{CO}, \mathrm{PPh}_{3}$ or $\mathrm{AsPh}_{3}$, decreases in length as expected from the trans influence found for ligands in tungsten $(0)$ carbonyl complexes: (largest trans-influence, longest W-C3 trans bond) carbonyl > phosphine > arsine $[32,35]$. By considering $\mathrm{d}(\mathrm{W}-\mathrm{C} 1)$ of the novel complexes as well as literature data [12], the 
trans-influence trend for the ligands of this series of tetracarbonyl tungsten $(0)$ complexes can be extended to read as follows: carbonyl $>$ carbene $>\mathrm{PPh}_{3}>\mathrm{AsPh}_{3}$. This trend varies primarily according to the $\pi$-acceptor ability of the ligand [32,39]. In all three complexes in Table 4 the furyl ring is in the anti conformation. It is also observed that the O7-C7-C6-O6 dihedral angle deviates more from $180^{\circ}$ as the cis group, $\mathrm{CO}, \mathrm{PPh}_{3}$ or $\mathrm{AsPh}_{3}$, increases in size.

Table 4. Selected bond lengths ( $\mathrm{A})$, bond angles $\left(^{\circ}\right)$, and dihedral angles $\left(^{\circ}\right)$ for cis$\left[\left(\mathrm{AsPh}_{3}\right)(\mathrm{CO})_{4} \mathrm{WC}(\mathrm{OEt})\left(\mathrm{C}_{4} \mathrm{H}_{3} \mathrm{O}\right)\right], 2$ and its analogues $-\left[(\mathrm{L})(\mathrm{CO})_{4} \mathrm{WC}(\mathrm{OEt})\left(\mathrm{C}_{4} \mathrm{H}_{3} \mathrm{O}\right)\right]$ with $\mathrm{L}=\mathrm{CO}$ or $\mathrm{PPh}_{3}$. Refer to Figure 3 for numbering scheme.

\begin{tabular}{|c|c|c|c|}
\hline & $\begin{array}{c}\mathrm{L}=\mathbf{C O}[38] \\
\text { anti }\end{array}$ & $\begin{array}{c}\mathbf{L}=\mathbf{P P h}_{\mathbf{3}}[12] \\
\text { cis-anti }(\mathbf{1})\end{array}$ & $\begin{array}{l}\mathrm{L}=\mathrm{AsPh}_{3} \\
\text { cis-anti (1) }\end{array}$ \\
\hline \multicolumn{4}{|l|}{ Bond length $(\AA)$} \\
\hline W-E & - & $2.5488(3)$ & $2.6282(4)$ \\
\hline W-C6 & $2.199(3)$ & $2.1712(13)$ & $2.178(3)$ \\
\hline $\mathrm{W}-\mathrm{C} 3^{\mathrm{a}}$ & $2.042(7)$ & $1.9870(15)$ & $1.978(4)$ \\
\hline W-C1 & $2.009(4)$ & $2.0185(16)$ & $2.017(4)$ \\
\hline $\mathrm{C} 3-\mathrm{O} 3^{\mathrm{a}}$ & $1.140(10)$ & $1.154(2)$ & $1.153(4)$ \\
\hline $\mathrm{C} 1-\mathrm{O} 1$ & $1.162(6)$ & $1.1442(2)$ & $1.147(4)$ \\
\hline C6-C7 & $1.353(11)$ & $1.4475(19)$ & $1.447(5)$ \\
\hline C6-O6 & $1.406(10)$ & $1.3286(18)$ & $1.330(4)$ \\
\hline \multicolumn{4}{|l|}{ Bond angle $\left(^{\circ}\right)$} \\
\hline W-C6-C7 & $129.8(6)$ & $124.70(10)$ & $124.4(2)$ \\
\hline W-C6-O6 & $124.3(6)$ & $130.76(10)$ & $130.9(2)$ \\
\hline C7-C6-O6 & $105.8(3)$ & $104.45(11)$ & $104.6(3)$ \\
\hline \multicolumn{4}{|l|}{ Dihedral angle $\left({ }^{\circ}\right)$} \\
\hline O7-C7-C6-O6 & $-180.000(1)$ & $-175.64(12)$ & $-174.2(3)$ \\
\hline
\end{tabular}

${ }^{\mathrm{a}}$ For $\mathrm{E}=\mathrm{CO}$ this represents average $\mathrm{W}-\mathrm{CO}$ cis or average $\mathrm{C}-\mathrm{O}$ cis

\subsection{DFT study}

A density functional theory (DFT) computational chemistry study was done to determine the lowest energy conformers of complexes 1-4. The relative gas phase electronic energies of the different conformers of complexes 1-4, as illustrated in Schemes 1 and 2 of the Supplementary Information, are reported in Table 5 for the hybrid functional B3LYP, the dispersion corrected B3LYP-D3 functional and the M06 functional. Generally, the energy of the trans isomers are higher than that of the cis isomers. Especially when dispersion effects on DFT were used, the energy difference between cis and trans isomers increased. Results 
obtained with the B3LYP-D3 functional and the M06 functional, that has been developed for studying transition metal complexes and conformational energies, are very similar. The small energy differences obtained between some of the conformers of the same complex $(<0.04$ $\mathrm{eV}$, see the numbers indicated in bold font in Table 5) indicate that in these cases more than one conformer is experimentally possible. However, the minimum energy MO6 conformation exactly matches the structures obtained by X-ray crystallography for $\mathbf{1}$ - $\mathbf{4}$.

For complexes 1 and $\mathbf{3}$ the cis-syn (1) and cis-syn (2) conformers were found to have the lowest energy, while for complex 2 the cis-anti (1) and cis-anti (2) conformers were found to have the lowest energy. The only difference between the two conformers in each case is the position of $\mathrm{AsPh}_{3}$ with respect to the orientation of the carbene ligand. For complex 4 the cissyn-anti (1), cis-syn-anti (2), cis-syn-syn (1) and cis-syn-syn (2) conformers were found to be equi-energetic within $0.04 \mathrm{eV}$. These four conformers differ in the position of $\mathrm{AsPh}_{3}$ with respect to the orientation of the carbene ligand, as well as the orientation of the second thienyl ring (syn or anti), see Figure 7. It was previously shown that the barrier to rotation of a thienyl ring in related carbene complexes is low $(0.1-0.3 \mathrm{eV})$ and that rotation of the thienyl ring is possible in the gas and solution phase [40]. For each of complexes 1-4, the experimental crystal structure obtained thus agrees with the structure of the one of the lowest energy conformers.
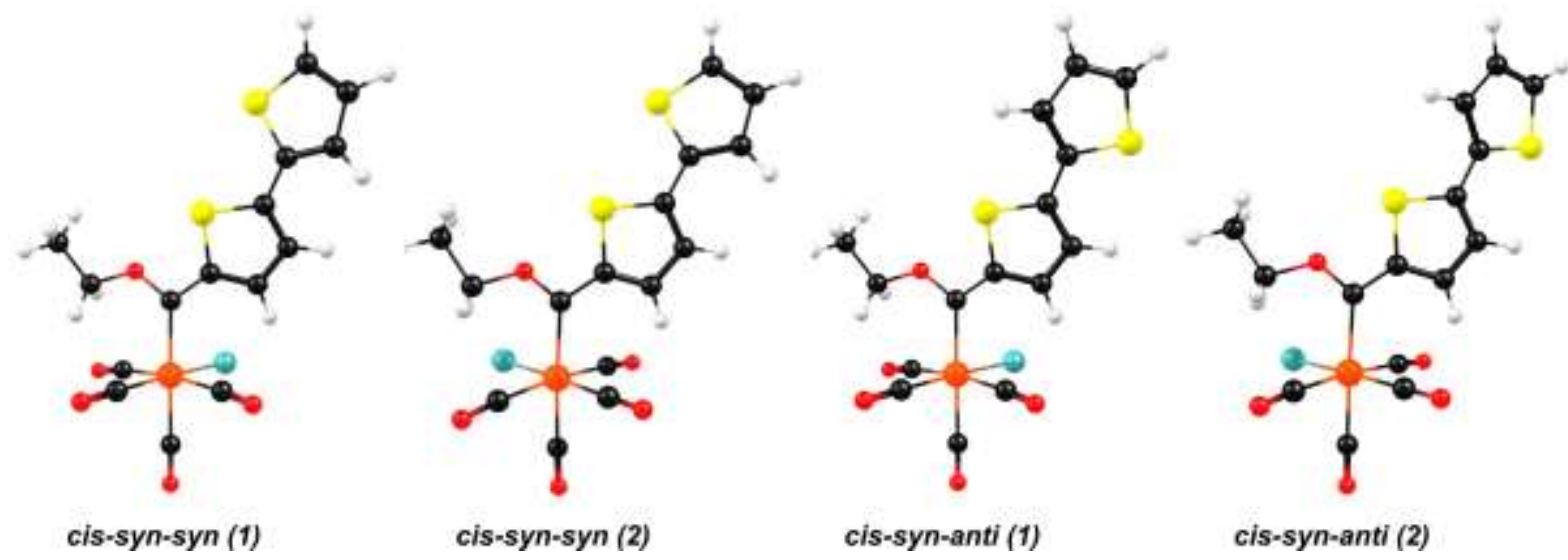

Figure 7. B3LYP-optimized gas phase geometries for the four lowest energy conformers of 4 . The crystal structure of $\mathbf{4}$ corresponds to the cis-syn-anti (2) conformer. Phenyl rings on As were removed for clarity. Colour code (online version): W (orange), C (black), S (yellow), As (blue), O (red) and H (white). 
Table 5. DFT-calculated gas phase electronic energies for possible conformers of $\mathrm{W}$ carbene complexes 1-4. The energy of the lowest energy conformers are indicated in bold font.

\begin{tabular}{|c|c|c|c|c|c|}
\hline \multirow[t]{2}{*}{ Complex } & \multirow[t]{2}{*}{ Conformation $^{\mathrm{a}}$} & \multicolumn{3}{|c|}{ DFT calculated relative energy $(\mathrm{eV})$} & \multirow[t]{2}{*}{ Crystal structure } \\
\hline & & B3LYP & B3LYP-D3 & M06 & \\
\hline \multirow[t]{6}{*}{1} & cis-anti (1) & 0.14 & 0.13 & 0.15 & \\
\hline & cis-anti (2) & 0.12 & 0.14 & 0.10 & \\
\hline & cis-syn (1) & $\mathbf{0 . 0 0}$ & $\mathbf{0 . 0 0}$ & 0.02 & \\
\hline & cis-syn (2) & 0.01 & 0.01 & 0.00 & Crystal structure \\
\hline & trans-anti & 0.19 & 0.35 & 0.32 & \\
\hline & trans-syn & 0.09 & 0.24 & 0.25 & \\
\hline \multirow[t]{6}{*}{2} & cis-anti (1) & $\mathbf{0 . 0 0}$ & $\mathbf{0 . 0 0}$ & $\mathbf{0 . 0 0}$ & Crystal structure \\
\hline & cis-anti (2) & $\mathbf{0 . 0 3}$ & 0.07 & $\mathbf{0 . 0 3}$ & \\
\hline & cis-syn (1) & 0.09 & 0.09 & 0.08 & \\
\hline & cis-syn (2) & 0.10 & 0.10 & 0.07 & \\
\hline & trans-anti & 0.08 & 0.25 & 0.23 & \\
\hline & trans-syn & 0.18 & 0.32 & 0.31 & \\
\hline \multirow[t]{6}{*}{3} & cis-anti (1) & 0.24 & 0.21 & 0.22 & \\
\hline & cis-anti (2) & 0.23 & 0.13 & 0.18 & \\
\hline & cis-syn (1) & 0.00 & $\mathbf{0 . 0 3}$ & 0.04 & \\
\hline & cis-syn (2) & 0.04 & $\mathbf{0 . 0 0}$ & 0.00 & Crystal structure \\
\hline & trans-anti & 0.33 & 0.43 & 0.45 & \\
\hline & trans-syn & 0.12 & 0.27 & 0.28 & \\
\hline \multirow[t]{12}{*}{4} & cis-anti-anti (1) & 0.19 & 0.14 & 0.05 & \\
\hline & cis-anti-anti (2) & 0.16 & 0.24 & 0.14 & \\
\hline & cis-anti-syn (1) & 0.14 & 0.08 & 0.05 & \\
\hline & cis-anti-syn (2) & 0.12 & 0.19 & 0.11 & \\
\hline & cis-syn-anti (1) & 0.00 & 0.00 & 0.02 & \\
\hline & cis-syn-anti (2) & 0.02 & $\mathbf{0 . 0 7}$ & 0.00 & Crystal structure \\
\hline & cis-syn-syn (1) & $\mathbf{0 . 0 3}$ & 0.05 & 0.05 & \\
\hline & cis-syn-syn (2) & 0.04 & 0.06 & $\mathbf{0 . 0 3}$ & \\
\hline & trans-anti-anti & 0.21 & 0.41 & 0.36 & \\
\hline & trans-anti-syn & 0.17 & 0.37 & 0.30 & \\
\hline & trans-syn-anti & 0.09 & 0.31 & 0.25 & \\
\hline & trans-syn-syn & 0.12 & 0.35 & 0.28 & \\
\hline
\end{tabular}

${ }^{a}$ Enantiomers exist for each isomer. Since the DFT calculated energies of enantiomers are identical, energies of enantiomers are not indicated.

From a crystallographic perspective, no discernible interactions were observed that may explain the preference of the observed orientation. However, natural bond order calculations (NBO) [41] for these complexes have shown that a stabilizing interaction between a lone pair of oxygen of the furyl ring and the anti-bonding orbital on the carbonyl ligand $\mathrm{C} 2-\mathrm{O} 2$ has a second order perturbation theory interaction energy of $3.43 \mathrm{~kJ} / \mathrm{mol}(0.036 \mathrm{eV}$, Figure 8$)$. This may be put forward as a reason for complex 2 to exhibit the anti conformation of the two heteroatoms of the two carbene substituents. All three of the other complexes exhibit a syn conformation. 


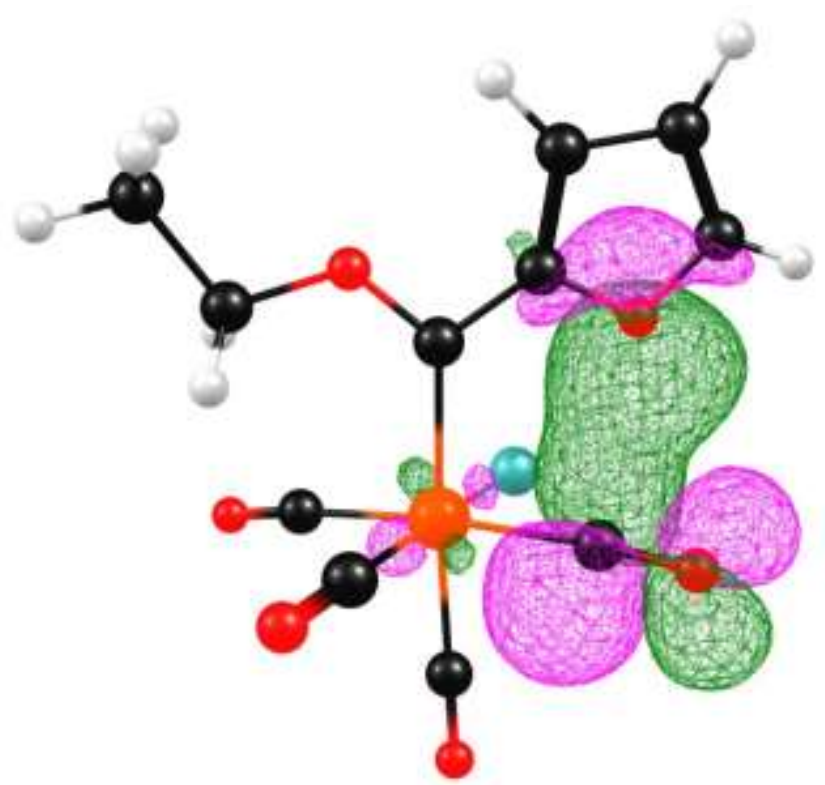

Figure 8. NBO interaction between the lone pair on the oxygen of the furyl ring and the anti-bonding orbital on the carbonyl group C2-O2 in 2. The three phenyl rings on As were removed for clarity. Colour code (online version): W (orange), C (black), S (yellow), As (blue), O (red) and H (white).

\section{Conclusions}

An experimental X-ray and theoretical DFT study of four novel triphenylarsine-substituted Fischer ethoxycarbene complexes of the type $\left[\left(\mathrm{AsPh}_{3}\right)(\mathrm{CO})_{4} \mathrm{WC}(\mathrm{OEt})(\mathrm{Ar})\right]$ for $\mathrm{Ar}=2$-thienyl (1), 2-furyl (2), 2-(N-methyl)pyrrolyl (3) and 2,2'-bithienyl (4) showed that the structure isolated in the solid state of a specific complex, generally agreed with the DFT calculated lowest energy conformation. Only the cis-substituted complexes could be isolated experimentally. The small DFT calculated energy difference between some of the cis conformers of the same complex, indicates that in some cases more than one conformer are experimentally feasible. The strong trans influence of the CO ligand was evident from this study, followed by the carbene ligand, compared to that of the $\mathrm{PPh}_{3}$ and $\mathrm{AsPh}_{3}$ ligands. Evidence confirming the superior $\pi$-acceptor ability of phosphines over arsines could be demonstrated from ${ }^{13} \mathrm{C}$ and crystallographic data, but not from data obtained from the IR.

\section{Supplementary data}

1416431 - 1416434 contain the supplementary crystallographic data for this article. Copies of the information may be obtained free of charge from the Director, CCDC, 12 Union Road, Cambridge CB2 1EZ, UK (Fax: +44 1223 336033; Email: deposit@ccdc.cam.ac.uk or www.ccdc.cam.ac.uk). The optimized coordinates of the DFT calculations and 
crystallographic supplementary material are provided in the electronic supplementary information.

\section{Disclosure statement}

The authors declare no conflict of interest.

\section{Funding}

This work has received support from the Norwegian Supercomputing Program (NOTUR) through a grant of computer time (Grant No. NN4654K) (JC), the South African National Research Foundation (JC, ML) and the Central Research Fund of the University of the Free State, Bloemfontein (JC) and the University of Pretoria (ML).

\section{References}

[1] E. O. Fischer and A. Maasböl, Angew. Chem. Int. Ed., 1964, 3, 580-581.

[2] E. O. Fischer and U. Klabunde, J. Am. Chem. Soc., 1967, 89, 7141-7142.

[3] E. O. Fischer and R. Aumann, Chem. Ber., 1969, 102, 1495-1503.

[4] E. O. Fischer and K Richter, Chem. Ber., 1976, 109, 1140-1157.

[5] N. Szesni, B. Weibert and H. Fischer, Inorg. Chim. Acta, 2004, 357, 1789-1798.

[6] P. K. Baker, M. E. Harman, M. B. Hursthouse, A. I. Karaulov, A. J. Lavery, K. M. A. Malik, D. J. Muldoon and A. Shawcross, J. Organomet. Chem., 1995, 494, 205-213.

[7] F. R. Kreissl, M. Wolfgruber and U. Thewalt, J. Organomet. Chem., 1986, 317, 175-186.

[8] R. J. Barton, S. K. Manocha, B. E. Robertson and L. M. Mihichuk, Canad. J. Chem., $1998,76,245-253$.

[9] S. K. Manocha, L. M. Mihichuk, R. J. Barton and B. E. Robertson, Acta Crystallogr., Sect. C: Cryst. Struct. Commun., 1991, 47, 722-725.

[10] C. L. Bergstrom and R. L. Luck, Inorg. Chim. Acta, 2001, 318, 77-83.

[11] H. Werner and H. Rascher, Inorg. Chim. Acta, 1968, 2, 181-185.

[12] M. Landman, R. Pretorius, R. Fraser, B. E. Buitendach, M. M. Conradie, P. H. van Rooyen and J. Conradie, Electrochim. Acta, 2014, 130, 104-118.

[13] G. H. Spies and R. J. Angelici, Organometallics, 1987, 6, 1897-1903.

[14] H. Meerwein, Org. Syn., 1966, 46, 120-121.

[15] C. Crause, H. Görls and S. Lotz, Dalton Trans., 2005, 1649-1657. 
[16] S. Aoki, T. Fujimura and E. Nakamura, J. Am. Chem. Soc., 1992, 114, 2985-2990.

[17] A. J. Olivier, M.Sc. Dissertation: Novel carbene complexes with pyrrole ligands, University of Pretoria, 2001.

[18] M. Landman, J. Ramontja, M. van Staden, D. I. Bezuidenhout, P. H. van Rooyen, D. C. Liles and S. Lotz, Inorg. Chim. Acta, 2010, 363, 705-717.

[19] A. D. Becke, Phys. Rev. A: Atomic, Molecular, and Optical Physics, 1988, 38, 30983100 .

[20] C. T. Lee, W. T. Yang and R. G. Parr, Phys. Rev. B: Condensed Matter and Materials Physics, 1988, 37, 785-.

[21] J. Stephens, F. J. Devlin, C.F. Chabalowski, M. J. Frisch, J. Phys. Chem. 1994, 98, 11623-11627.

[22] S. Grimme, J. Antony, S. Ehrlich H. Krieg, J. Chem. Phys., 2010, 132, 154104.

[23] Y. Zhao, D.G. Truh, Acc. Chem. Res., 2008, 41, 147.

[24] M.J. Frisch, G.W. Trucks, H.B. Schlegel, G.E. Scuseria, M.A. Robb, J.R. Cheeseman, G. Scalmani, V. Barone, B. Mennucci, G.A. Petersson, H. Nakatsuji, M. Caricato, X. Li, H.P. Hratchian, A.F. Izmaylov, J. Bloino, G. Zheng, J.L. Sonnenberg, M. Hada, M. Ehara, K. Toyota, R. Fukuda, J. Hasegawa, M. Ishida, T. Nakajima, Y. Honda, O. Kitao, H. Nakai, T. Vreven, J.A. Montgomery (Jr), J.E. Peralta, F. Ogliaro, M. Bearpark, J.J. Heyd, E. Brothers, K.N. Kudin, V.N. Staroverov, T. Keith, R. Kobayashi, J. Normand, K. Raghavachari, A. Rendell, J.C. Burant, S.S. Iyengar, J. Tomasi, M. Cossi, N. Rega, J.M. Millam, M. Klene, J.E. Knox, J.B. Cross, V. Bakken, C. Adamo, J. Jaramillo, R. Gomperts, R.E. Stratmann, O. Yazyev, A.J. Austin, R. Cammi, C. Pomelli, J.W. Ochterski, R.L. Martin, K. Morokuma, V.G. Zakrzewski, G.A. Voth, P. Salvador, J.J. Dannenberg, S. Dapprich, A.D. Daniels, O. Farkas, J.B. Foresman, J.V. Ortiz, J. Cioslowski and D. J. Fox, Gaussian 09, Revision B.01, Gaussian, Inc., Wallingford, CT, 2013.

[25] F. Weigend and R. Ahlrichs, Phys. Chem. Chem. Phys., 2005, 7, 3297-3305.

[26] APEX2 (including SAINT and SADABS), Bruker AXS Inc., Madison, WI, 2012.

[27] G. M. Sheldrick, Acta Crystallogr. Section A, 2008, 64, 112-122.

[28] L. J. J. Faruggia, J. Appl. Crystallogr., 1997, 30, 565-566.

[29] E. O. Fischer and H. Fischer, Chem. Ber., 1974, 107, 673-679. 
[30] L. Lancelotti, R. Tubino, S. Luzzati, E. Licandro, E. Maiorana and A. Papagni, Synthetic Metals, 1998, 93, 27-32.

[31] P. S. Braterman, D. W. Milne, E. W. Randall and E. Rosenberg, J. Chem. Soc., Dalton Trans., 1973, 1027-1031.

[32] W Buchner, W.A. Schenk. Inorg. Chem. 23, 132 (1984).

[33] T.G Appleton, H.C Clark, L.E. Manzer. Coord. Chem. Rev., 10, 335 (1973).

[34] Cambridge Structural Database (CSD), Version 5.36, Feb 2015 update, reference codes:

TIHPOR, ZABNEV01, GIVQEH, HEWZAK, SUQMEW, VITQEU, VITQEU, ZABNEV and ZABNIZ.

[35] M. J. Aroney, I. E. Buys, M. S. Davies and T. W. Hambley, J. Chem. Soc., Dalton Trans., 1994, 2827-2834.

[36] S. Thompson, H. R. Wessels, R. Fraser, P. H. van Rooyen, D. C. Liles and M. Landman, J. Mol. Struct., 2014, 1060, 111-118.

[37] S. Lotz, C. Crause, A. J. Olivier, D. C. Liles, H. Görls, M. Landman, D. I. Bezuidenhout, Dalton Trans., 2009, 697-710.

[38] M. Landman, R. Pretorius, B.E. Buitendach, P.H. van Rooyen and J. Conradie, Organometallics, 2013, 32, 5491-5503.

[39] W. A. Schenk, W. Buchner, Inorg. Chim. Acta, 1983, 70, 189-196.

[40] M. Landman, R. Fraser, L. Twigge and J. Conradie, J. Coord. Chem., 2015, 68, 23882408.

[41] (a) J.P. Foster, F. Weinhold, J. Am. Chem. Soc. 102 (1980) 7211. (b) A.E. Reed, F. Weinhold, J. Chem. Phys. 83 (1985) 1736. (c) A.E. Reed, R.B. Weinstock, F. Weinhold, J. Chem. Phys. 83 (1985) 735. (d) A.E. Reed, L.A. Curtiss, F. Weinhold, Chem. Rev. 88 (1988) 899. 